\title{
SO, WHAT DO WE TALK ABOUT? O DISCURSO POLÍtICO E A IMAGEM CORPÓREA EM «THIERRY"
}

Rodrigo Lacerda ${ }^{1}$

Hoje em dia, as pessoas que filmamos nos documentários estão conscientes, ainda que, por vezes, superficialmente, das politicas de representação a que estão sujeitas. Esta realidade pode produzir uma friç̧ão entre as expectativas do indivíduo $e$ do realizador. Partindo da experiência de produção do documentário Thierry (2012), o artigo analisa alguns dos conflitos e confluências entre o registo do discurso politico e as exploraçôes da imagem corpórea (MacDougall 2006).

Palavras-chave: filme etnográfico; imagem corpórea; trabalho sexual; sindicalismo

Cozinha de uma casa do East End de Londres. Tarde. Pergunto: "Ready for the camera?" Thierry murmura: "Ah?" Repito: "Ready for the camera?" Thierry acena que sim, mete as mãos nos bolsos e olha para a câmara. Sorriso tímido, mas sedutor. Silêncio longo. Thierry tira o telemóvel da algibeira, olha-o e volta a guarda-lo. Sorve um gole do chá que tinha colocado em cima da mesa de apoio, encosta-se no sofá e cruza os braços. Pergunta: "So, what do we talk about?"

Este foi o primeiro plano que gravei e é assim que começa o filme. ${ }^{2}$ Thierry queria que ficasse registado o seu discurso político de activista e de presidente da secção dos trabalhadores

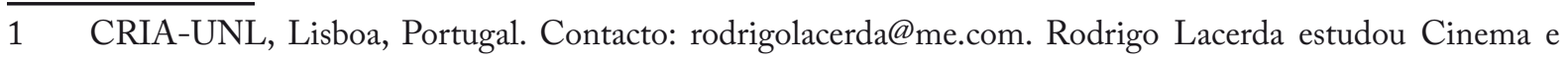
Televisão na London Metropolitan University e National Film and Televison School, no Reino Unido, e é Mestre em Antropologia, especialização Culturas Visuais, pela Faculdade de Ciências Sociais e Humanas da Universidade Nova de Lisboa, doutorando em Antropologia na mesma faculdade.

2 O documentário Thierry foi realizado no âmbito do seminário Atelier de Imagem, orientado pela Professora Catarina Alves Costa e integrado no Mestrado de Antropologia, especialização Culturas Visuais, da Faculdade de Ciências Sociais e Humanas da Universidade Nova de Lisboa. A minha intenção era utilizar as imagens capturadas para produzir este exercício, mas também iniciar a elaboração de um filme mais longo que, através da personalidade poliédrica do Thierry, permitisse reflectir sobre alguns temas que considero pertinentes: trabalho sexual, activismo político e construção do eu. Mas os nossos temas de estudo têm uma vida própria porque fazem parte da própria vida. Thierry apaixonou-se, regressou a França, abandonou o trabalho sexual e é o candidato do partido Europe Écologie Les Verts (EELV) à câmara de Paris nas eleições autárquicas de 2014. 
do sexo do sindicato $\mathrm{GMB}^{3}$ do Reino Unido. Eu, por outro lado, influenciado pela minha formação em cinema e antropologia, desejava filmar o seu quotidiano de trabalho e lazer. A tensão entre as palavras politicamente ordenadas e a imagem corporal (MacDougall 2006) extravasava para a inquietação das filmagens.

\section{PrÉ-Produção}

O filme Thierry (2012) é sobre a pessoa Thierry Schaffauser. Aquando das filmagens, ele vivia em Londres e trabalhava como prostituto em sistema indoors recorrendo à internet. Concluíra recentemente o mestrado em British Women History no London Metropolitan University e era um activista empenhado nas questões dos direitos LGBT e dos trabalhadores do sexo. Dois anos antes, tinha sido eleito presidente do "sex workers branch" do GMB. Conheci-o em 2010 durante a produção, em colaboração com Rita Alcaire, de um documentário televisivo ${ }^{4}$ para a $\mathrm{RTP}^{5}$ sobre o tema dos direitos laborais dos trabalhadores do sexo em Portugal. Na altura, tinha ficado impressionado com a sua argumentação durante a entrevista e comecei a ponderar a realização de um filme que pudesse representar uma visão mais pessoal sobre a sua profissão, o activismo político, a sexualidade, a multiplicidade identitária, a migração cultural ${ }^{6}$ e a precariedade laboral no mundo ocidental.

Em 2012, iniciei essa aventura. Antes de viajar para Londres, tentei discutir o projecto com o Thierry através da internet, mas, após aceitar a ideia, ele tornou-se relativamente monossilábico. Na noite anterior ao início das filmagens, encontramo-nos em sua casa para delinear um plano de rodagem. Pela primeira vez, ele mostrou-se um pouco contrariado com a abordagem observacional, argumentando que a sua vida era entediante e que o que tinha de interessante para comunicar era o seu discurso. O que filmar? Uma ida às compras? Ao ginásio? ("Mas eu nem vou muito. Se calhar, devia ir mais ...") A fazer um depósito no banco? Devido à sua actividade política, social e sindical, Thierry já tinha sido várias vezes entrevistado pelos media e estava à espera destes quadros de quotidiano encenado que são frequentemente utilizados nas reportagens televisivas como planos de corte entre excertos de entrevista. ${ }^{7}$ Nas últimas décadas, enquanto documentaristas e antropólogos habituamo-nos cada vez mais a chegar a terrenos que foram transformados em terra queimada pelos media e cientistas sociais devido a abordagens que estabeleceram expectativas de gestos, desilusões com representações e ausência de feedback. Situações em que os sujeitos foram usados para um objecto de estudo e/ou como objectos.

3 O GMB (General, Municipal, Boilermakers and Allied Trade Union) foi constituído pela fusão de vários sindicatos e é, hoje em dia, o terceiro maior afiliado do Partido Trabalhista do Reino Unido. O GMB da região de Londres possui uma abordagem diferente e, por vezes, controversa das demais secções. No sentido de combater a redução de trabalhadores sindicalizados, a circunscrição londrina tem expandido a sua acção a novas áreas e indústrias, incluindo trabalhadores do sexo, condutores de táxis não-oficiais (minicabs) e trabalhadores de sweatshops (Lopes 2006: 106-108).

4 Das Norves às Cinco (2012), 54', Realização Rita Alcaire e Rodrigo Lacerda, Produção PNG Pictures e RTP. 5 RTP (Rádio e Televisão de Portugal) é a estação pública portuguesa.

6 Thierry é francês, mas emigrara para o Reino Unido devido à eleição de Nicolas Sarkozy para Presidente da República.

7 As televisões em sinal aberto no Reino Unido transmitem vários documentários em horário nobre apesar de estes adoptarem um estilo mais próximo da reportagem e recorrerem a muitas entrevistas. 
Thierry questionava também a pertinência política destes gestos do quotidiano. $\mathrm{Na}$ sua opinião, a luta da comunidade LGBT e, mais recentemente, dos profissionais do sexo pelos seus direitos sucumbiu à ideia de que, para serem respeitados, têm que ser representados enquanto elementos sociais normalizados, abdicando de uma radicalidade política que ele considera implícita à sua sexualidade e profissão. Enquadrado num movimento de queer politics com origem nos anos sessenta e que tem sido sucessivamente actualizado, Thierry critica as aspirações dos activistas LGBT de acederem ao casamento burguês ou ao exército, ${ }^{8}$ ao mesmo tempo que ignoram os direitos de outras minorias e as diferenças de classe. Como ele disse nessa noite: "Hoje em dia, em Inglaterra, um homem gay com dinheiro tem quase os mesmos direitos e regalias que a maioria da população. E se for um sem abrigo gay?”

Mas havia algo mais, aparentemente contraditório, que lhe causava algumas reticências em relação à abordagem observacional. Apesar de ser o presidente da secção de trabalhadores do sexo do GMB, Thierry recusava corporalizar-se e individualizar-se. Ele só queria aparecer e ser representado enquanto porta-voz da organização e, por isso, pedia que apenas registassem o seu discurso político. Nesse sentido, procurava apagar, dentro do possível, as suas idiossincrasias e, de certo modo, a sua imagem, uma vez que considerava as ideias e o movimento mais importantes. Por outro lado, eu advogava que a mais valia do documentário é exactamente aquilo que David MacDougal denominou como "imagem corpórea".

No seu último livro, MacDougall (2006) propôs-se reexaminar a relação entre ver, pensar e saber e a natureza complexa do pensamento produzido por estas variáveis. Para este autor, as imagens fotográficas são corpóreas, isto é, o seu significado não pode ser apreendido recorrendo apenas à linguagem verbal que, normalmente, associamos ao pensamento, mas tem que ser compreendido através do corpo em diversas dimensões: o corpo do que é filmado, o corpo do realizador e o corpo do espectador. Além disso, recorrendo às ideias de Alfred Gell (1998) sobre a agencialidade da arte, MacDougall (2006: 30) argumenta que o filme constitui-se também como um corpo com agencialidade própria: "Beyond influence or aesthetics or meaning, films are made to become objects in the world, to exist in their own right" Nesse sentido, os filmes, como outros objectos, adquirem uma presença material própria.

A corporalidade da imagem possui, assim, uma agencialidade múltipla e complexa. Segundo Roland Barthes, existe uma conexão inseparável com o referente na imagem indexical que os torna aparentemente indistinguíveis: "Por natureza, a Fotografia [...] tem qualquer coisa de tautológico: nela, um cachimbo é sempre um cachimbo, infalivelmente. Dir-se-ia que a Fotografia traz sempre consigo o seu referente [...]” (Barthes 2012 (1980): 13) Uma imagem de Thierry, na sua infinitude de pormenores, é, portanto, uma imagem de Thierry. Não se pretende aqui advogar uma transparência da imagem de base fotográfica que, como já foi analisado (por exemplo, Tagg [1988], Hall [1997], Pinney [1997]), é influenciada por factores culturais e ideológicos. Propõem-se antes sublinhar que, para além destes factores, existe uma materialidade e

8 Na altura das filmagens, o "Coalition for Equal Marriage" tinha realizado um pequeno filme distribuído pelo youtube em que um grupo de militares regressava a casa. Alguns eram recebidos por mulheres e um deles por um homem. O clip tinha-se tornado viral e o Thierry estava furioso com a utilização do movimento LGBT para a promoção do exército. Ver em <http://www.youtube.com/watch?v=a54UBWFXsF4>. 
ligação ao real que subsiste e que, em vez de produzir um conhecimento claro e directo, conduz a um "discourse of risk and indeterminacy":

Through their stubbornness, photograhic images dispute their consecrated meanings (what Barthes called
the studium) or at least have the potential to undercut them. In films the complexity of people and objects
implicitly resists the theories and explanations in which the film enlists them, sometimes suggesting over
explanations or no explanations at all. In this sense, then, film is always a discourse of risk and indeterminacy.
[...] For all the ways in which photographic images oversimplify and aggressively impose their message (as
they often do in advertising, for example), they are intrinsically tentative, oscillating between meaning and
the self-sufficiency of their subjects. (MacDougall 2006: 6)

Para Thierry, a individualização e a dificuldade de controlar a imagem indexical surgiam como elementos perigosos. Para mim, a exploração das potencialidades da indeterminação e da corporalidade da imagem eram o modo de chegar àqueles que nos ouviam e viam: o corpo da audiência. Após uma longa discussão, Thierry aceitou reticente a abordagem observacional e estabelecemos um plano de rodagem para aquela semana. No dia seguinte, iríamos filmar o quotidiano em casa ("mesmo que não acontecesse nada ..."); no sábado, tentaríamos registar o encontro com a candidata socialista francesa às eleições legislativas pelo círculo do norte da Europa e a festa de anos de uma amiga; na segunda-feira, iríamos visitar e filmar uma conversa com a antropóloga Ana Lopes que, como parte da sua tese de doutoramento, fundou, em colaboração com profissionais do sexo, o International Union of Sex Workers (IUSW) que, posteriormente, se aliou ao GMB ( $c f$. Lopes 2006); na terça-feira, filmaríamos a participação do Thierry na manifestação do $1^{\circ}$ Maio como representante da secção dos trabalhadores do sexo do sindicato (a principal razão pela qual eu escolhi iniciar as filmagens naquela altura).

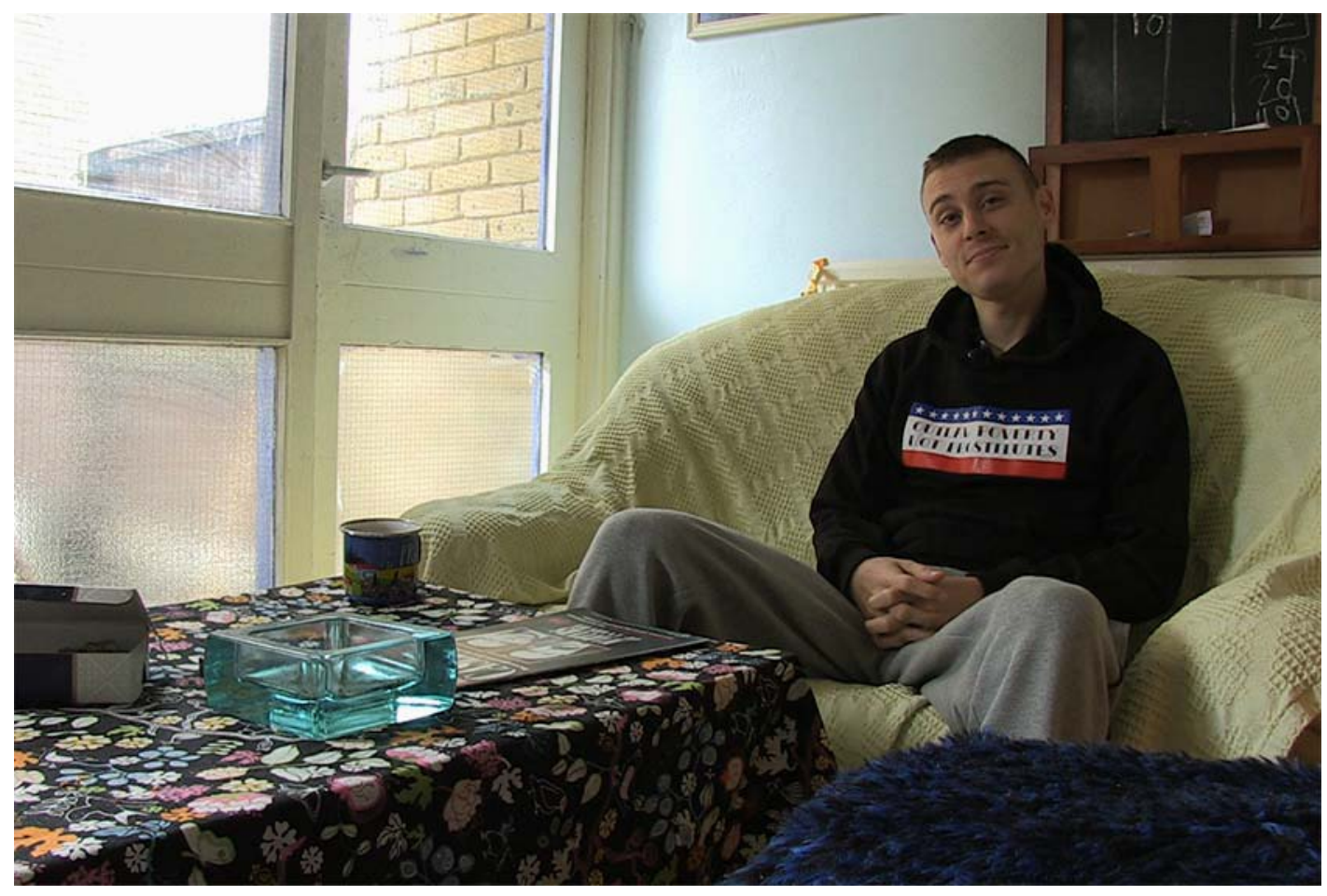

Primeiro plano do documentário «Thierry». 


\section{Rodagem}

Contudo, no dia seguinte, quando comecei a filmar, Thierry perguntou: "So, what do we talk about?". A importância do discurso político regressava e, apesar de lhe relembrar a conversa da noite anterior, ele mostrava-se irredutível sobre a sua disponibilidade para só dar uma entrevista. Achei que a melhor estratégia seria ceder e conversámos durante algumas horas sobre o sindicato, profissão, identidade, etc. O seu discurso é mesmo interessante e o meu conhecimento prévio sobre o tema do trabalho sexual permitiu estabelecer um diálogo para lá de uma abordagem superficial. Apesar destas gravações não terem sido incluídas na montagem final, elas foram importantes para nos conhecermos melhor e iniciarmos uma relação de intimidade, camaradagem e cumplicidade que foram essenciais para o desenvolvimento do documentário. Por vezes, na ânsia de filmar os nossos projectos, esquecemo-nos que estamos a estabelecer uma relação pessoal com os nossos sujeitos em que a partilha de palavras, refeições, copos, amizade, etc. é essencial.

Várias horas depois, senti que tínhamos assegurado um entendimento comum básico que me permitia tentar convencê-lo outra vez a filmar o seu quotidiano. Desta vez, o Thierry acedeu. Foi buscar o computador ao quarto (permitindo-me ver uma parte da casa que ele queria inicialmente ocultar) e trouxe-o para a cozinha. Ligou o site do gaydar ${ }^{9}$ e foi lendo o facebook, o Le Monde, etc. enquanto esperava que o contactassem. Finalmente, recebeu uma mensagem e pareceu que ia haver a possibilidade de um trabalho. $\mathrm{O}$ potencial cliente demorava a responder e o Thierry, impaciente, ia-me explicando o que sentia e a sua opinião sobre a profissão. Mas estas palavras, nomeadamente nas suas interjeições, silêncios e hesitações, eram muito diferentes do discurso político limpo que me tinha entregue horas antes:

Gosto de ter sexo, mas não gosto de falar com as pessoas a tentar vender alguma coisa. Nem sei se ele percebe que eu sou um escort. Provavelmente percebe. Não sei. Se não lerem o perfil. Ou sabem, mas ... tentam obter de graça. Porque, na verdade, estou só a repetir o que já está no meu perfil. Não sei ... Suponho que precisam disso antes de conhecer alguém. Eu ri-me porque é exactamente ...É engraçado porque ... Tens que falar como se estivesses excitado e tu estás ... Acho que quando sei que eles vão chegar, estou mentalmente preparado e a sentir-me excitado para ter sexo em breve. A parte irritante é que, enquanto não os conheces e tens o dinheiro, não sabes se vais fazer dinheiro. Porque há muita gente que marca um encontro e não aparece. A parte irritante é que estás a fazer isto tudo, mas não sabes se vale alguma coisa. Essa é a parte que eu odeio no trabalho.

Por fim, o contacto revelou que não era um cliente e o Thierry demonstrou a sua frustração. Naquele breve momento, voltei a compreender que, por muito interessante que o seu discurso fosse, o recurso a uma câmara permitia-me captar um conjunto de pequenos gestos e expressões que o verbo não conseguiria exprimir com aquela fisicalidade: a impaciência, o tempo, o revirar dos dedos quando descobre que não vai ter trabalho, que não vai ser pago.

Mas Thierry esqueceu rapidamente o falso cliente ao reparar que uma amiga no facebook lhe perguntava se ele sabia alguma coisa sobre um homem que a queria levar para a Nigéria. Ele reconheceu o nome e consultou o ficheiro de computador com os dados de bad clients. Como

9 Gaydar é um site de encontros para homossexuais masculinos que possui uma secção específica para escorts. Naquele momento, o Thierry estava a usar a funcionalidade chat em que não é possível saber se se está a falar com um escort sem consultar o perfil pessoal. 
explicou enquanto transmitia a informação à colega (murmurando a última frase entredentes e com uma expressão entre o desprezo e a raiva contida):

Temos várias maneiras de nos alertarmos uns aos outros sobre clientes falsos, pessoas perigosas ... Porque há tanta gente que desperdiça o nosso tempo e as pessoas querem saber. Eles sabem que os escorts não vão telefonar à polícia, por isso, há muita gente que nos tenta enganar. E também pensam que somos estúpidos e que somos um alvo fácil.

Como é possível observar, as palavras também podem ressoar a experiência com que estão imbuídas. E, contudo, no cinema, tal como no nosso quotidiano, elas possuem uma outra complexidade. Segundo MacDougall, enquanto que a escrita é principalmente cumulativa, o cinema é compósito, isto é, observamos, numa determinada cena, concomitantemente, vários elementos e acontecimentos que estabelecem relações entre si. Estas associações são simultaneamente concretas e perceptuais.

[...] the composite vision of photographs and films offers a way of exploring connections in the social world often lost in writing, much as writing offers a way of recording conclusions about society unavailable to film. I am thinking here not only of how people and things are culturally organized in their social settings, but also how individuals perceive their surroundings and their fellows in the physical and sensory terms, and how this affects how they themselves behave. This is not only a matter of interpersonal relations. We live among cultural practices and culturally mediated environments that exert powerful effects upon us. (MacDougall 2006: 38)

Nesse sentido, quando vemos alguém verbalizar determinado discurso, estamos a experienciar um fenómeno complexo em que observamos vários elementos em simultâneo (as palavras, os gestos, o enquadramento, etc.) que se relacionam e contaminam. Alguns filmes levaram a experiência da entrevista a um certo extremo. Fengming, a Chinese Memoir (2007), de Wang Bing, por exemplo, é quase exclusivamente constituído por uma entrevista a uma mulher que relata a história da sua vida (e, implicitamente, da China). Ao longo de três horas, vamos absorvendo a informação cumulativa do discurso, mas também as pausas, as palavras sublinhadas, o corpo tenso e controlado da entrevistada, a luz que muito lentamente desaparece e que leva o realizador a finalmente interromper a entrevista para pedir para acender um candeeiro.

De facto, depois dos dois últimos momentos acima descritos, Thierry tem o discurso que até hoje reverbera em mim:

Eu quero tempo livre para o activismo e isso tudo. A razão porque faço trabalho sexual não é tanto pelo dinheiro, mas para ter tempo livre. Para ser flexível e poder estudar, escrever e fazer activismo. Se eu estivesse a tentar trabalhar sempre e mais, não sei se teria a mesma liberdade. Acho que ficaria entediado a certa altura. Talvez fizesse mais dinheiro ... (pausa) Mas não vejo o sentido de ficar rico se todos os outros à tua volta continuam pobres. Se eu ficar rico, terá que ser com a minha comunidade. Não sei ...

Como foi acima explicado, a imagem inclui muito mais do que estas palavras e é essa conjugação que produz o seu efeito no meu corpo de realizador. Thierry hesita em certos momentos. Por vezes, sorri. O olhar dirige-se para a câmara e rapidamente se afasta. A sua expressão muda constantemente enquanto acompanha o raciocínio que procura verbalizar. Trata-se de um grande plano que capta a sua cara, os armários de cozinha e uma fotografia de Beth Ditto arrancada de uma revista. Esta personagem é uma cantora lésbica politicamente activa e com uma elevada notoridade pública, que teve, tal como Thierry, durante algum tempo, uma coluna de opinião no jornal britânico The Guardian. Para quem a conhece, estabelece-se naquele plano um paralelismo fortuito e feliz. Mas será que é um paralelismo? Quem é que colocou ali a ima- 
gem? O Thierry ou um colega de apartamento? Será que ele realmente se identifica com ela? A relação indexical com o real da imagem fotográfica produz relações compósitas que o realizador às vezes não consegue controlar e que a audiência dificilmente deixará de interpretar, mesmo que inconscientemente. Tal como argumenta MacDougall (2006: 41): “[...] this richness is potentially uncontrollable. You can see the problem. You both want and don't want the combative power that shots offer, for they constantly drift toward the actual complexity and indeterminacy of the experienced world."

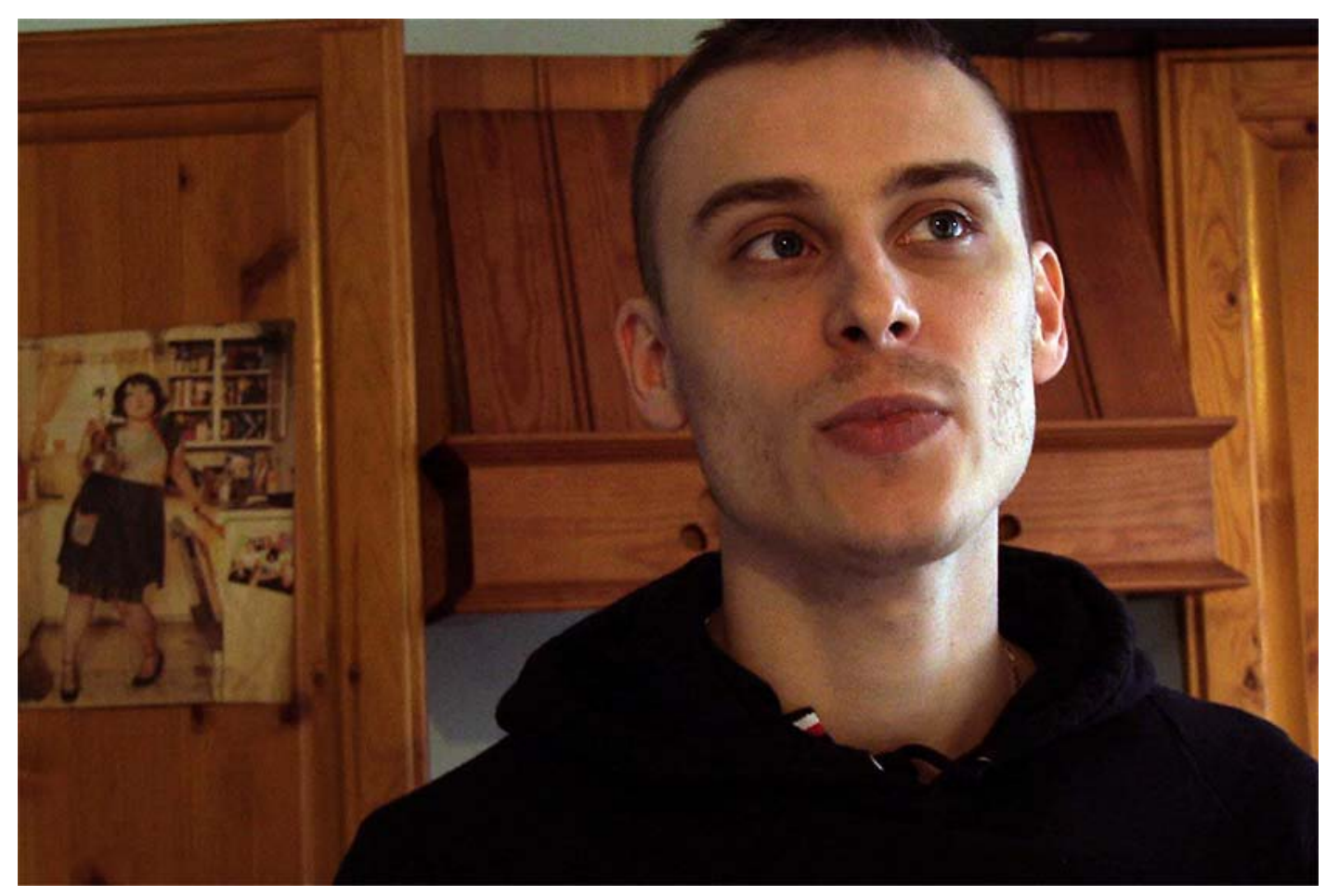

Thierry com imagem de Beth Ditto ao fundo.

$\mathrm{Na}$ manhã do $1^{\circ}$ de Maio estava a chover e, quando cheguei a casa do Thierry, nem ele nem o colega de apartamento, que também fazia parte do sindicato, pareciam especialmente motivados para irem à manifestação. $\mathrm{O}$ amigo chegou mesmo a comentar que estava farto de actividades políticas e que preferia ficar em casa a fazer dinheiro. Tive alguma dificuldade em entender o ambiente ligeiramente irascível e considerei que estava relacionado com o mau tempo e terem acordado cedo. Só durante a manifestação é que compreendi que eles eram os únicos a dar a cara pelo sindicato, numa luta constante, inglória e solitária que devia ser difícil de manter. Esta reflexão não está presente no documentário. O processo de filmagem pressupõe a sintonia de um conjunto de variáveis de difícil controlo que oscilam entre a previsão, a improvisação e a sorte. No caso do quadro supramencionado, eu não estava preparado: não esperava aquele ambiente e demorei algum tempo a montar a câmara. Além disso, havia muito ruído matinal (torneira da água, esquentador, outras pessoas da casa a entrar e a sair) que inutilizou alguns planos. Mas, por vezes, as limitações corpóreas do cinema também se impõem. Naquela manhã, havia algo de imaterial no ambiente que tornava a sua presença no vídeo provavelmente impossível de corporalizar.

Se eu não consegui capturar a atmosfera daquele início de dia, o que se seguiu só poderia ser satisfatoriamente traduzido por uma câmara. Thierry decidiu ir vestido de drag para a 
manifestação, provavelmente, porque estes eventos são lugares, por excelência, de performance, mas penso que também pela sua recusa em se individualizar dentro do movimento, recorrendo, assim, a um alter ego. Contudo, no dia a dia, ele veste-se e move-se num estilo descontraído de streetwear: calças desportivas, t-shirt larga, cabelo curto e boné. Por isso, eu não conseguia imaginar aquele corpo transformado em drag e pensei que as roupas femininas seriam uma pele muito secundária e algo carnavalesca. Porém, durante o processo de transformação, que pude filmar, ocorreu uma mudança gradual e profunda. $\mathrm{O}$ seu corpo foi-se tornando mais hirto, os movimentos mais precisos, a voz mais aguda. A sua personalidade mudou. $\mathrm{O}$ rapaz meio encurvado que filmara a ler o Le Monde, admirava-se agora ao espelho num estilo que ele considerou "ligeiramente Lady Gaga". O Thierry tímido que me perguntara, "So, what do we talk about?", brincava agora comigo, exigindo que eu fosse útil e mandasse vir um táxi. Thierry demonstrava que toda a personalidade extravasa os limites pressupostos, incluindo os do objecto do nosso estudo.

De facto, naquele dia, no seu novo corpo, Thierry era outro e começou a apreciar a atenção da câmara. Enquanto corríamos atrasados para a manifestação, eu ia capturando alguns planos gerais para mais tarde utilizar na montagem. A certa altura, quando estava a filmar um contrapicado, Thierry passou ostensivamente à frente da objectiva, irrompendo pelo meio da manifestação com uma faixa do sindicato a ser arrastada pelo chão e gritando: "Olhem para a minha faixa! Sou um sindicalista! Sou um sindicalista! Olhem para a minha faixa! Tenho uma faixa grande!" Havia uma performance desencadeada pelo seu alter ego, pela minha câmara e pelos outros inúmeros dispositivos audiovisuais presentes.

Mas o filme também revela a minha performance fílmica, isto é, a experiência de quem segura e vê o mundo através da câmara. Neste documentário, tinha optado por não utilizar o tripé devido ao limite de peso da bagagem de avião e às filmagens anteriores que tinha realizado com jovens. Uma vez que estes normalmente se movimentam muito, a utilização do tripé implica o recurso a planos curtos (ilidindo a noção de tempo que eu queria explorar) ou o emprego de planos muito gerais (originando uma distância que seria contraproducente para um retrato intimista). Esta opção produziu imagens menos estáveis, especialmente porque eu ainda me estava a habituar a uma câmara diferente. Contudo, alguns solavancos são representações do meu corpo em confronto com a realidade que queria transmitir à audiência. Segundo MacDougall (2006: 54), "In viewing a film, [...] we also respond to the filmmaker's body as we experience it through the decisions that guide the movements of the camera, how it frame events, and in matters of proximity and positioning in relation to the subjects." Por exemplo, no plano supramencionado em que o Thierry irrompe pela manifestação, eu fui apanhado de surpresa. Durante alguns segundos, a imagem oscila porque tentava compreender o que tinha acontecido e, a seguir, porque corria atrás do meu sujeito. Durante a montagem, poderia ter dividido o plano em dois, ignorando o excerto menos estável ou só utilizando a segunda parte. Mas optei por manter o plano inteiro porque este também mostra o meu corpo-câmara, ou, recorrendo à famosa expressão de Jean Rouch (2011 [1989]: 55-59), o meu ciné-transe. 


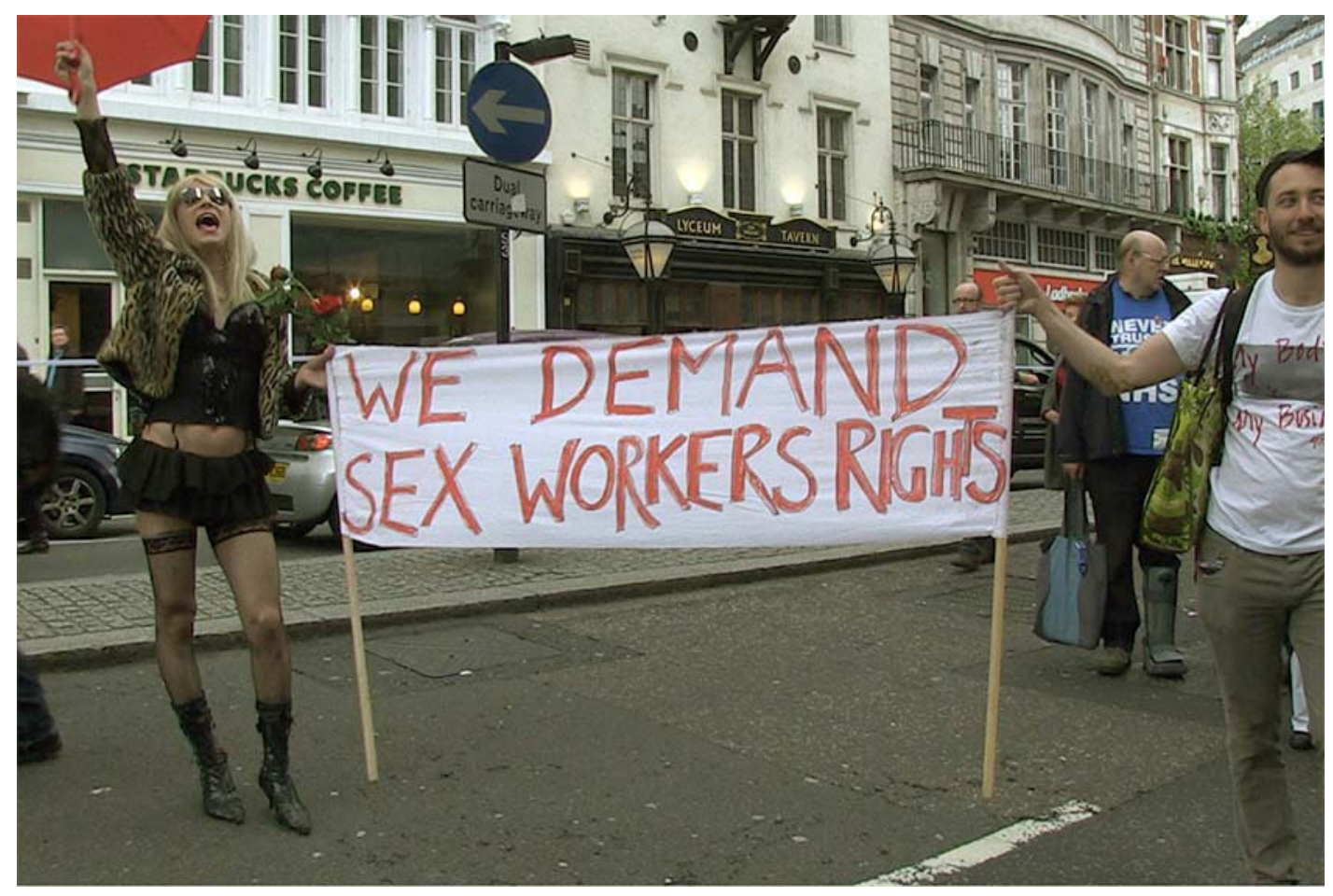

Thierry (esquerda) na manifestação do $1^{\circ}$ de Maio.

\section{Montagem}

De regresso a Portugal, deixei os brutos repousarem durante alguns dias para estabelecer uma distanciação. Quando os revi, sabia que a minha experiência não ia, de uma forma mágica, emergir da sua visualização. Era necessário trabalhar estas imagens para construir e reconstruir o que sentira, mas também disponibilizar-me para o que elas me permitiam experienciar pela primeira vez. Mas como urdir este corpo que se impunha e que simultaneamente apresentava limitações e potencialidades inerentes ao espírito compósito da imagem indexical? Como arquitectar uma linha narrativa que ligasse estes quadros, isto é, como encadear o visível mantendo o invisível - provavelmente, o mais importante - subjacente? Apesar do documentário de observação se basear num realismo cinematográfico, "[...] realism in art", como André Bazin (2005 [1971]: 26) sublinhou, "can only be achieved in one way - through artifice."

Havia momentos que, como acima aludi, não tinha conseguido capturar. Outros quadros não possuíam força para serem incluídos, como as longas horas de entrevista ao Thierry no início do primeiro dia e a conversa entre ele e Ana Lopes. Havia três sequências que sabia que queria incorporar e que descrevi na secção anterior do artigo: o falso cliente; a lista de "bad clients"; a manifestação do $1^{\circ}$ de Maio, incluindo a transformação para drag. Esta era a informação seleccionada. Mas o que fazer com estes brutos? Não queria estabelecer uma simples linha narrativa constituída por uma encadeamento de quadros. Procurava antes uma paisagem onde eu e o espectador nos pudéssemos imergir neste novo corpo. Tal como na recorrente metáfora do escultor, passei várias horas revendo e experimentando na timeline, disponível para o que cada plano me poderia fazer sentir. A frieza do "So, what do we talk about?" do início; o lento abrir do seu mundo; a exposição de me deixar filmar a transfiguração do seu corpo; o sorriso 
largo para a câmara no final da manifestação e em que me apresentava aos outros como a pessoa que estava a fazer um filme sobre ele denominado "A Boring Life" ... O que as imagens me mostravam é que eu também estava ali sem nunca aparecer. Não se tratava de um simples caso de reflexividade em que se reconhecia a presença do realizador e da câmara. Essa atitude tinha sido assumida por mim desde o início por razões éticas e estéticas, mas também práticas: eu não queria filmar o seu discurso político, mas sabia que partes das nossas conversas teriam que ser incluídas. Mas além desta reflexividade, o que as imagens me mostravam era a evolução da nossa relação ao longo daqueles dias - uma progressiva intimidade e cumplicidade entre o corpo fílmico e o corpo do realizador que, através da montagem, eu queria transformar numa progressiva intimidade e cumplicidade com o corpo do espectador.

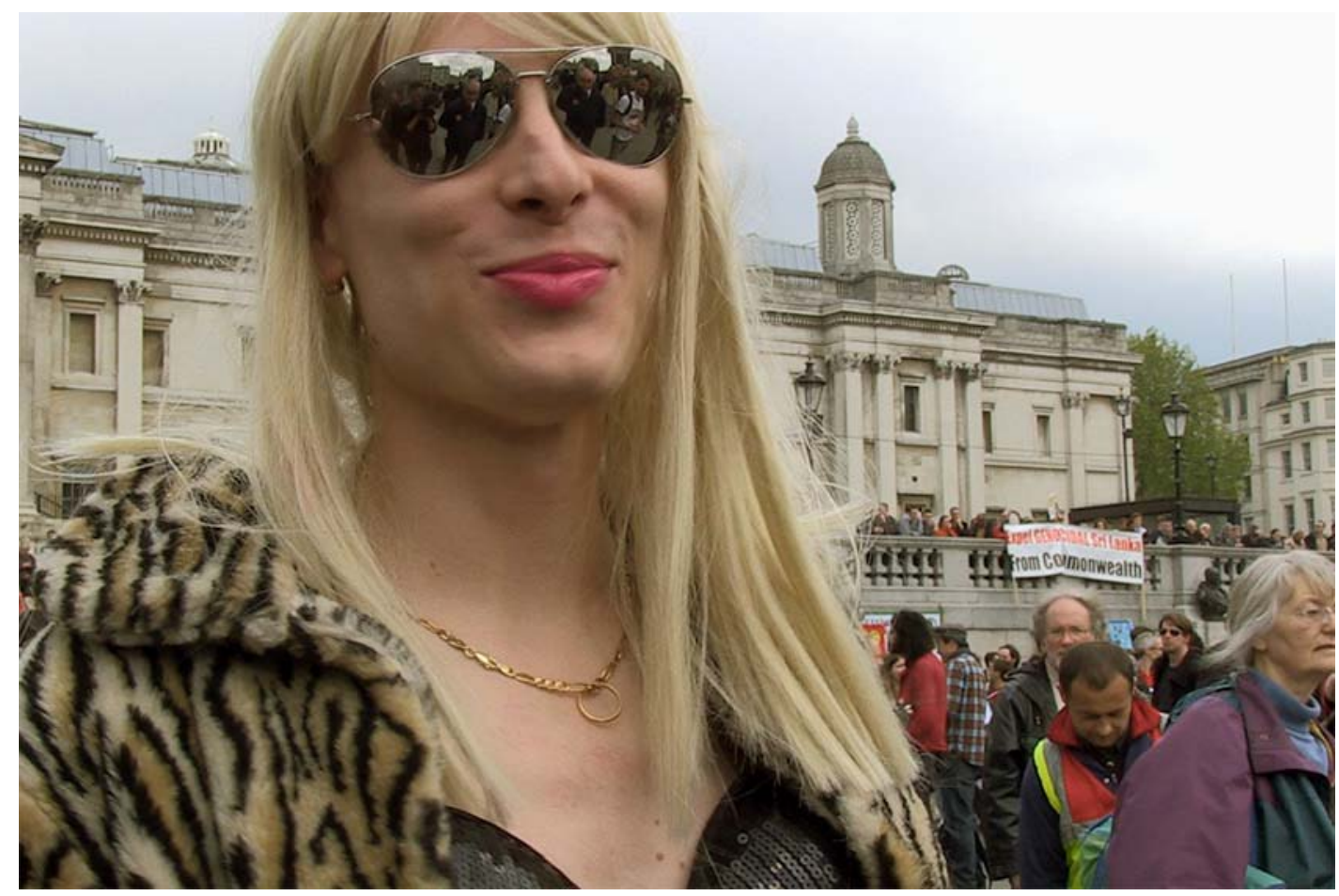

Thierry (e eu no reflexo dos óculos) no final da manifestação.

Esta opção, que implicou uma montagem tendencialmente cronológica, também foi relevante para lidar com a questão polémica da representação do trabalho sexual enquanto trabalho. Nos primeiros minutos, antes de ter qualquer informação sobre a sua profissão, o espectador conhece Thierry e o seu espaço: ele a beber chá na cozinha, a brincar com o gato, a lavar a louça, a ir buscar o computador ao quarto, o seu sorriso tímido, mas sedutor. Progressivamente, recorrendo a planos relativamente longos (em que a utilização da câmara à mão foi determinante), o filme vai mostrando aspectos mais íntimos e, por vezes, como em todos nós, contraditórios da sua vida e personalidade. No final, após a manifestação, Thierry vai lanchar à cantina de Saint Martin's e nós já não o observamos. De certo modo, já nos preparamos para sentar e partilhar a refeição com ele. $\mathrm{O}$ documentário termina. 


\section{«THIERRY», THIERRY E EU}

Thierry é um pequeno filme que realizei depois de outras obras mais longas e que demoraram vários anos a produzir, mas foi uma experiência determinante para encontrar o meu olhar, o meu corpo realizador. No passado, senti-me espartilhado entre um cinema puramente observacional em que o realizador-observador desaparece e, paradoxalmente, se torna omnisciente e omnipotente, e os documentários supostamente mais informativos baseados em entrevistas ou voz off. Com Thierry, não cedi necessariamente a uma abordagem colaborativa. Mas ao aceitar e potenciar a interacção entre o corpo filmado e o corpo do realizador, produzi um corpo fílmico que, espero, seja sentido, na sua dimensão política e pessoal, pelo corpo da audiência. O filme Thierry é, assim, em suma, a expressão da experiência desses breves dias com o Thierry, a pessoa. A experiência de um encontro e, por vezes, de um recontro.

\section{Biblografia}

Barthes, Roland. 2012 (1980). A Câmara Clara. Lisboa: Edições 70.

Bazin, André. 2005 (1971). André Bazin, Vol. 2. Berkeley and Los Angeles: University of California Press.

Gell, Alfred. 1998. Art and Agency. An Anthropological Theory. Oxford and New York: Oxford University Press.

Hall, Stuart. 1997. "The Work of Representation." Pp. 13-74 in Representation. Cultural Representations and Signifying Practices, edited by Stuart Hall. London, Thousand Oaks, New Delhi: Sage Publications.

Lopes, Ana. 2006. Trabalhadores do Sexo Uni-vos. Organização Laboral na Indústria do Sexo. Lisboa: Publicações Dom Quixote.

MacDougall, David. 2006. The Corporeal Image. Princeton, New Jersey: Princeton University Press.

Pinney, Christopher. 1997. Camera Indica, The Social Life of Indian Photographic Images. London: Reaktion Books.

Rouch, Jean. 2011 (1989). “A Câmara Como Elo Social: Cinema Directo e Cine-Transe.” Pp. 55-59 in Jean Rouch, coordenado por José Manuel Costa e Luís Miguel Oliveira. Lisboa: Cinemateca Portuguesa - Museu do Cinema.

Tagg, John. 1988. The Burden of Representation. Essays on Photographies and Histories. Minneapolis: University of Minnesota Press.

So, What do We talk about? Political discourse and the corporeal IMAGe IN "THIERRY»

People we film today for documentaries are aware, even if superficially, of the politics of representation they are subjected to. This fact can produce a friction between the expectations of the individual and those of the filmmaker. Based on the author's experience during the production of the documentary 
Thierry (2012), the article analyses some of the conflicts and convergences between the shooting of political discourse and the explorations of the corporeal image (MacDougall 2006).

Keywords: ethnographic film; corporeal image; sex work; trade unionism

Recebido em: 2013-11-29

Aceito em: 2014-03-07 